\title{
Leadership Styles in Childcare Directors
}

\author{
Michelle Grantham-Caston ${ }^{1}$ [D . Cynthia Fontcuberta DiCarlo ${ }^{1}$
}

Accepted: 29 October 2021 / Published online: 20 November 2021

(C) The Author(s), under exclusive licence to Springer Nature B.V. 2021

\begin{abstract}
Leadership is of paramount importance to any organization, as leaders can set the tone for the organization's employees. The path to leadership in childcare can be markedly different from other professions, as there is no qualifying criteria; however, previous research has identified that for leaders to be effective they must possess skills, characteristics, and traits of effective leadership. The present study used The Multifactor Leadership Questionnaire (MLQ) (in Bass and Avolio, Multifactor leadership questionnaire (TM), Mind Garden, Inc., Menlo Park, 1995) with childcare directors to determine their self-identified leadership styles including transformational, transactional, and passive/avoidant to determine if their leadership style was consistent with recommendations from the field. Results suggest that childcare directors who remain in the role of managers (displaying either transactional or passive/avoidant leadership styles) do not provide the leadership needed to provide a high quality of education for young children, which is consistent with previous research. This research echoes concern from the field for credentialing of childcare directors.
\end{abstract}

Keywords Early care and education $\cdot$ Childcare $\cdot$ Administration $\cdot$ Leadership

\section{Leadership Styles in Childcare Directors}

Leadership is a complex topic "whereby an individual influences a group of individuals to achieve a common goal." (Northouse, 2016, p. 6). Successful leaders connect and influence people to achieve a common goal even when there is difficulty as "leadership lies in the manner in which leaders see and act on their own and their followers' values and motivations" (Burns, 1979, p. 19). These definitions revolve around human connections and communication which is like-minded with the seminal work of Burns, in that "the effectiveness of leaders must be judged not by their press clippings but by actual social change measured by intent and by the satisfaction of human needs and expectations." (1979, p. 3). Communication and relatability to other humans is a key to quality leaders, as leaders must form relationships through communication efforts so as to get to know and understand their team members for the benefit of the group. There is a vast amount of research surrounding K-12 in the

Cynthia Fontcuberta DiCarlo

Cdicar2@1su.edu

Michelle Grantham-Caston

Mgran19@1su.edu

1 Louisiana State University, Baton Rouge, LA, USA
United States, however historically, limited research and importance have been placed on early childhood leadership (Berger, 2016; Goffin \& Janke, 2013; Wise \& Wright, 2012). This is troublesome as early childhood education (ECE) has been an agenda item with local legislation as the problem of closing the gap between ECE and formal (K-12) education persists.

Wolcott's (2003) ethnographic piece, The Man in the Principal's Office, is the story of a school system, the economy of a school district, and one principal's daily routine in the 1970's. The story provides insights into the daily workings of a school and the role a leader, which is connected to many of the same elements and relational networks still present for educational leaders today. These include the daily administrative task of managing the budget, achieving school wide goals, and motivating teachers, children, parents, and the community. In childcare, Rodd (1997) found that directors spent their time on a variety of maintenance tasks including: managing and supervising staff (34\%), contact with parents and professionals (22\%), staff support and development (16\%), managing the budget $(11 \%)$, and coordinating roles $(11 \%)$. The difference between a principal and director is that principals tend to have support staff such as a clerk, secretary, and/ or assistant principal, and directors in many cases are the 
support staff. Thus, when examining the roles of principal and director, both are positions of leading, however, directors seem to not have as many people surrounding them for support as principals.

The path of a K-12 administrator varies by state according to their state's principal standards and certification requirements. According to the Education Commission of the States (Scott, 2020) every state in the United States and the District of Columbia have standards that guide their school leadership polices. Of the 50 states plus District of Columbia, 37 states require at least three years teaching experiences and a master's degree for initial school leadership certification.

In the state where this study was conducted, to be an administrator in the public-school system requires a master's degree, state certification, five or more years of classroom teaching at the elementary school level, and a minimum of 27 semester hours of graduate credit. Within the 27 semester hours, there must be 3 semesters in each of the following courses: theory of educational administration, school principalship, supervision of instruction, educational research, history/philosophy of education, school curriculum, school law, school finance, school personnel administration; 3 semester hours in one of the following courses: school facilities, school community relations, and program development and evaluation; and receipt of a passing score on the Praxis II School Leaders Licensure Assessment. In recognition of the importance of ongoing professional development, new principals are required to participate in a two-year Principal Internship Program once hired.

The path for a childcare director in the state where this study was conducted mandates that each center have a director "who is responsible for planning, managing and controlling the center's daily activities as well as responding to parental concerns and ensuring that minimum licensing requirements are met" (LDOE, 2021, p. 19). The minimum qualifications as are stated and outlined by the state is that the director be at least 21 years old and meet one of the following requirements: (a) a bachelor's degree and 12 credit hours of child development or education, (b) an associate of arts degree in child development or closely related area, (c) a national administrator credential, (d) a child development associate credential (CDA), (e) a diploma from a postsecondary technical early childhood education training program approved by the Board of Regents or correspondence course approved by the Licensing Division, (f) 3 years of experience as a director or staff in a licensed early learning center. All the above-mentioned qualifications $(\mathrm{a}-\mathrm{f})$ can be in a comparable setting, subject to approval by the Licensing Division. They must all include at least one-year experience in a licensed early learning center and depending on the requirement the individual has met, will need a certain amount of professional development (clock hours) in child development (LDOE, 2021).

\section{Leadership Styles}

Implicit leadership theories are conceptualized as everyday images of leaders comprising traits, skills, and behaviors. The literature is robust with examples of the rationale for moving into leadership, as well as the path to becoming a successful leader (Charry, 2012). Some researchers have found that leadership falls under one of three categories "leadership as process or relationship, leadership as combination of traits or personality characteristics, or leadership as certain behaviors [skills]" (Amanchukwu et al., 2015 , p. 7). Those who radiate toward leadership possess the traits and skill of "intelligence, alertness, insight, responsibility, initiative, persistence, self-confidence and sociability" (Northouse, 2016, p. 20).

Transformational leadership seeks to change or transform an organization by 'assessing followers' motives, satisfying their needs, and treating them as full human beings" (Northouse, 2016, p. 161). As a principal/director, this leadership style is shared and affects many stakeholder groups, including children, parents, teachers, staff, administration, and the community. A transformational leader allows others to interject allowing for empowerment of multiple stakeholder groups focusing on the process of achieving positive outcomes (Bush \& Glover, 2014). Transactional leadership "defines expectations and promotes performance to achieve these levels" (Avolio et al., 2004) Transformational leaders motivate their followers with rewards if the followers satisfy an agreed upon condition. The literature is clear that transformational leadership works best and has a "positive impact on work performance" (Rusliza \& Fawzy, 2016, p. 206) and gains commitment from the followers.

\section{Early Childhood Leadership Development}

The problem many directors encounter is they do not see themselves in the role of leader and this is likely due to the path taken to directorship. Many directors did not set out to be directors; they were identified because they were good teachers (Bloom, 1997; Talan et al., 2014). Bloom refers to this as the improvisation, citing Bateson (1989) who defined the improvisational path as being one where the individual discovers who they are "along the way, rather than pursuing a vision..." (p. 1). This notion of the improvisational director is evident, as $90 \%$ of directors surveyed were former teachers with only $27 \%$ reporting that they were prepared for leadership (Bloom, 1997; Bloom et al., 2013; Talan, et al., 2014). 
Childcare directors who remain in the role of teacher or manager must transition their mindset to one of leadership. In this role they must be comfortable charting the course for their organization to increase educational quality and adherence to recommended practices. Shifting to a leadership mindset means utilizing not only their working knowledge of child development, and moral purpose, but also one's personal traits and skills (Bloom, 2000; Northouse, 2016). These can be defined as "intelligence, alertness, insight, responsibility, initiative, persistence, self-confidence and sociability" (Northouse, 2016, p. 20).

As many directors are not traditionally trained for administration, efforts have been made at the local level to prepare the administrative workforce in childcare. For example, the local administrative credentials for childcare directors of this southern state appear to cover content necessary for appropriate staff to child ratio, maintaining appropriate documentation for licensing regulations, but there appears to be a missing component-leadership professional development. While leaders cannot be effective if they are not equipped to manage the day-to-day operation of the center, managing is not the same as a leading. It may be said then that management focuses on maintenance and leadership on development of a vision (Bloom, 2000; Northouse, 2016). Rodd (2006) notes that both management and leadership are needed in early childhood programs, but there is a difference between the two. Rodd defines management as tending to daily operation of the program, while maintaining the existing condition. Leadership is forward thinking and is concerned with improvement of the organization through vision and philosophy (Rodd, 2006).

The need and demand for "effective leadership and appropriate training....is an increasingly important element in providing high-quality provision for the early years" (SirajBlatchford \& Manni, 2006, p. 290). Research has found that high performing directors in childcare must be business minded, data driven, lifelong learners, all while having a clear vision to motivate, communicate and empower their staff (Coleman et al., 2015). These directors must create collaborative partnerships within the community and promote family engagement. To be an effective director one does not only focus on the qualities one possesses, but the ability to surround oneself with those who possess skills and traits they are lacking. The fact that there is an absence of programs supporting leadership for the early care profession, how do we increase the leadership preparation for early childhood facilities since the push down is affecting directors, in that their centers are rated based on the teachers' performances?

\section{Building Leadership for Early Childhood Directors}

Research suggests that "directors with greater levels of administrative training report significant gains in their level of competence and staff who work at these programs perceive the work environment to be more positive and productive" (Talan et al., 2014, p. 2). The McCormick Center for Early Childhood Leadership (2021, August 14) designed a model to build professional learning communities called Taking Charge of Change (TCC). TCC incorporated small group experiences, large group discussions, presentations, discussions, and role playing as a platform for professional learning. Through these programs directors have been empowered and left with an increased leadership practice that improved their programs. If programs as the two previously mentioned were incorporated to build a career ladder specific for content on "leadership history, theory and practice" (Hard \& Jonsdottir, 2013, p. 322), directors would have a clearly defined working knowledge of leadership versus management.

Research suggests that the recognition of the need for ongoing professional development in leadership makes leadership "visible and valued" and helps the leader "dealing with the complexity of change" (Coleman et al., 2015, p. 781). There have been some strides to address the need for increased opportunities for administrators in early childhood programs. However, although there are requirements in place for entry-level qualifications, there is nothing promoting increased standards on credential career pathways for different levels of the director rankings which would promote strong leadership. The current study sought to determine the director's self-perception of their leadership styles and examined the following research questions (1) With what leadership styles do early childhood leaders self-identify? (2) What other demographic variables contribute to early childhood leaders' self-perception of leadership styles?

\section{Method}

This study investigated leadership styles of childcare directors in one state within the United States, using the $M L Q$ $5 X$ Short Form. This survey was distributed using the Qualtrics@ Online Survey platform. The surveys were electronically distributed across the state to childcare directors. The MLQ 5X Short Form measures self-perceptions, while allowing for analysis of leadership styles and outcomes while determining any correlations.

\section{Setting and Participants}

For the purpose of this study, the parameters for inclusion in the study included directors of a Type III childcare center in 
one southern state. Type III childcare centers are those centers that can receive public funding (e.g., Child Care Assistance Program, Non-public Schools Early Childhood Development, Head Start) and/or receive quality star ratings. The researcher sent a short email with a Qualtrics@ survey link to the directors of 493 of the 1030 Type III childcare centers in the state. The researcher compiled a mass list of all the email addresses that could be found using the states website and data from the 2018 Performance Profile. This allowed for simple random sampling, with a normally distributed sample size (Hinkle et al., 2003) to an extensive population that geographically represented the target southern state.

The study employed voluntary participants with a total of 90 people opening the survey, 73 consented to participate in the study and four people did not consent after opening the survey. Of those that consented 66 people completed the survey; however, two participants did not complete every question. The survey received a $13.38 \%$ response rate and was within the expected $10-15 \%$ response rate for online studies (Fryrear, 2019).

According to the World Population Review (2021), the racial composition of this state is $62 \%$ Caucasian, $32 \%$ African American, 2\% two or more races, $1.73 \%$ Asian, $1.41 \%$ other, . $57 \%$ Native American, and .03\% Native Hawaiian. Of the study participants $(n=66) 52.4 \%$ Caucasian, $42.9 \%$ African American, 3.2\% Latino/Hispanic, and 1.6\% other. The demographics according to a 2019 estimate by the United States Census for the state is $62.9 \%$ Caucasian, 32.7\% African American, and 4.4\% other (Native, Asian, islander, other, multiple). In regard to reported levels of education $(n=62) 3$ held a high school diploma, 13 held a Child Development Associate (CDA), 6 held an associate degree, 20 held a bachelor's degree, 17 held a master's degree and 3 held a Ph.D.

\section{Measures and Procedures}

The MLQ 5X Short form is based on years of research in "public and private organizations, from CEO's of major corporations to non-supervisory project leaders" (Avolio et al., 2004 , p. 3). The tool measures behaviors and outcomes to assess leadership characteristics to identify the respondents' leadership style as either transformational, transactional, or passive avoidant. MLQ $5 X$ Short has several forms each consisting of 45 questions with a 5-point Likert-type scale ranging from one (unsure) to five (frequently, if not always) (Antonakis et al., 2003).

There are five subscales related to transformational including idealized attributes, as this leader is "admired, respected, and trusted" (Avolio et al., 2004, p. 103) because they focus on others personal attributes; whereas idealized behaviors focuses more on others values and beliefs of others for betterment of the organization; inspirational motivation, includes encouragement, optimism and enthusiasm; intellectual stimulation, is one who seeks different perspectives and new methods to solve problems; and individual consideration, meaning one who understands the needs of others and treats everyone equally as an individual.

There are two subscales related to transactional characteristics including contingent reward, as this leader often perceives themselves as a leader who "clarifies expectations and offer recognition when goals are achieved...result in individuals and groups achieving expected levels of performance" (Avolio et al., 2004, p. 104); management-byexception, is looking for mishaps so one can take corrective action. The passive/avoidant has two subscales including management by exception which is described as a passive leader who waits for things to happen before interfering; and laissez-faire which is described as a leader who avoids making decisions or being involved (Avolio et al., 2004).

The scale also measured outcomes of leaders' extra effort, effectiveness, and satisfaction. Extra effort is when a leader can get others to do more than they are required to do while increasing others willingness to try

harder to succeed (Avolio et al., 2004). Effectiveness refers to leaders who can aim to meet other's needs, and organizational requirements. Satisfaction with leadership is a characteristic that promotes working well with others.

All surveys were randomly distributed and anonymous to tap subjective perceptions of leadership characteristics (Parsons et al., 2003). The data were cleaned, and the $M L Q$ scoring key was used to group the items by scale to find the following characteristics transformational, transactional, and passive avoidant.

\section{Data Analysis}

The Qualtrics () software used for data collection is compatible with Statistical Package for the Social Sciences (SPSS). The data analysis with SPSS included descriptive statistics (i.e., frequency tables and graphs) and inferential statistics (i.e., independent samples t-test, Kendall Tau-b, crosstabulation). The frequency distribution (i.e., tables, graphs) describes the number of directors related to each leadership style and the means associated with each leadership style. Kendal Tau was used to measure the correlation between ordinal variables (i.e., education and extra effort) (Hinkle et al., 2003). A cross tabulation was used to analyze the relationship between variables. A t-test was used to determine if there was any significance between variables (i.e., education, characteristic of outcomes of leadership scale). 
Table 1 MLQ Short Form Leadership Characteristics

\begin{tabular}{lll}
\hline Leadership characteristics & $M$ & $S D$ \\
\hline Transformational & 4.25 & .514 \\
Transactional & 3.63 & .554 \\
Passive Avoidant & 1.80 & .422 \\
\hline
\end{tabular}

\section{Results}

\section{Self-Identified Leadership Style}

The leadership characteristics targeted in the $M L Q$ Short form include transformational, transactional, and passive avoidant leadership styles. The participants scored the 45 questions using a Likert scale ranging from 1 (not at all) to 5 (frequently, if not always). Table 1 presents the overall results from the data which indicated that of the 65 participants, the majority self-identified as transformational, overall mean of 4.25 out of 5 with a standard deviation of .514 , then transactional with an overall mean of 3.63 out of 5 and standard deviation of .554, and then passive avoidant leadership with an overall mean of 1.80 out of 5 and standard deviation .422 .

The descriptive statistics describe the data from the survey as it was computed for the different types of leadership styles (Table 2). Sixty-five participants were included in this calculation. Results for the transformational characteristic included five subscales. Subscale results are as follows: idealized attributes [IA or II (A)], resulting in a minimum score of 1.25 and a maximum score of 5.00 [range of $5, \mathrm{M}=4.12, \mathrm{SD}=.76$ ); idealized behaviors [IB or II (B)], resulting in a minimum score of 2.25 and a

Table 2 Descriptive statistics

\begin{tabular}{llllll}
\hline $\begin{array}{l}\text { Descriptive } \\
\text { measure }\end{array}$ & $\mathrm{N}$ & Minimum & Maximum & Mean & Std. deviation \\
\hline $\begin{array}{l}\text { Transformational } \\
\text { IA or II (A) }\end{array}$ & 65 & 1.25 & 5 & 4.12 & .757 \\
IB or II (B) & 65 & 2.25 & 5 & 4.28 & .535 \\
IM & 65 & 2.50 & 5 & 4.33 & .667 \\
IS & 65 & 2.25 & 5 & 4.12 & .591 \\
IC & 65 & 2.75 & 5 & 4.38 & .529 \\
Transactional & & & & & \\
CR & 65 & 1.75 & 5 & 4.26 & .644 \\
MBEA & 65 & 1.00 & 5 & 2.99 & .907 \\
Passive/avoidant & & & & & \\
MBEP & 65 & 1.00 & 3 & 1.65 & .565 \\
LF & 65 & 1.00 & 2.75 & 1.95 & .422 \\
Valid N & 65 & & & & \\
\hline
\end{tabular}

maximum score of 5.00 (range of $5, \mathrm{M}=4.28, \mathrm{SD}=.54$ ); inspirational motivation (IM), resulting in a minimum score of 2.50 and a maximum score of 5.00 (range of 5, $\mathrm{M}=4.33, \mathrm{SD}=.67$ ); intellectual stimulation (IS), resulting in a minimum score of 2.25 and a maximum score of 5.00 (range of $5, \mathrm{M}=4.12, \mathrm{SD}=.59$ ); and individual consideration (IC), resulting in a minimum score of 2.75 and a maximum score of 5.00 (range of $5, \mathrm{M}=4.38 \mathrm{SD}=.53$ ). Results for the two subscales of the transactional characteristics are as follows: contingent reward (CR), resulting in a minimum score of 1.75 and a maximum score of 5.00 (range of $5, \mathrm{M}=4.26, \mathrm{SD}=.64$ and managementby-exception (MBEA), resulting in a minimum score of 1.00 and a maximum score of 5.00 (range of $5, \mathrm{M}=2.99$, $\mathrm{SD}=.91$.

Results for the two subscales of the passive/avoidant characteristics are as follows: MBEP management by exception (MBEP) resulted in a minimum score of 1.00 and a maximum score of 3.00 (range of $5, \mathrm{M}=1.65$, $\mathrm{SD}=.57)$ and laissez-faire (LF) resulted in a minimum score of 1.00 and a maximum score of 2.75 (range of 5, $\mathrm{M}=1.95, \mathrm{SD}=.42$ ).

Table 3 presents a frequency analysis related to the subscales of transformational, transactional, and passive/avoidant leadership styles from the 65 participants. Transformational idealized attribute (IA) $16.7 \%$ of participants scored 4.50 with a mean of 4.12 and standard deviation of .757. Transformational idealized behaviors (IB) $18.2 \%$ of participants scored 4.25 with a mean of 4.28 and standard deviation of .535; Transformational inspirational motivation (IM) $24.2 \%$ of participants scored 5.00 with a mean of 4.33 and standard deviation of .667; Transformational intellectual stimulation (IS) $19.7 \%$ of participants scored 4.00 with a mean of 4.12 and standard deviation of .591; and Transformational individual consideration (IC) $22.7 \%$ of participants scored 5.00 with a

Table $3 M L Q$ short form subscale characteristics

\begin{tabular}{llll}
\hline Characteristics & \% of participants & $M$ & $S D$ \\
\hline Transformational & & & \\
IA & 16.7 & 4.12 & .757 \\
IB & 18.2 & 4.28 & .535 \\
IM & 24.2 & 4.33 & .667 \\
IS & 19.7 & 4.12 & .591 \\
IC & 22.7 & 4.38 & .529 \\
Transactional & & & \\
CR & 19.7 & 4.26 & .644 \\
MBEA & 16.7 & 2.99 & .907 \\
Passive/avoidant & & & \\
MBEP & 18.2 & 1.65 & .565 \\
LF & 22.7 & 1.95 & .422 \\
\hline
\end{tabular}


mean of 4.38 and standard deviation of .529. Transactional contingent reward (CR) $19.7 \%$ of participants scored 4.75 with a mean of 4.26 and standard deviation of .644; and Transactional management by exception (MBEA) $16.7 \%$ of participants scored 3.00 with a mean of 2.99 and standard deviation of .907. Passive avoidant management by exception (MBEP) $18.2 \%$ of participants scored 1.75 with a mean of 1.65 and standard deviation of .565; and Passive

Table 4 Education leadership

\begin{tabular}{llll}
\hline & $N$ & $M$ & $S D$ \\
\hline Transformational & & & \\
High school & 3 & 4.167 & .454 \\
CDA & 13 & 3.962 & .503 \\
Associate & 6 & 4.414 & 3.401 \\
Bachelor's & 20 & 4.359 & .454 \\
Master's & 17 & 4.290 & .612 \\
PhD & 3 & 4.367 & .454 \\
Transactional & & & \\
High school & 3 & 3.917 & .260 \\
CDA & 13 & 3.516 & .649 \\
Associate & 6 & 3.785 & .346 \\
Bachelor's & 20 & 3.692 & .476 \\
Master's & 17 & 3.500 & .476 \\
PhD & 3 & 3.708 & .382 \\
Passive avoidant & & & \\
High school & 3 & 1.833 & .191 \\
CDA & 13 & 1.990 & .522 \\
Associate & 6 & 1.542 & .303 \\
Bachelor's & 20 & 1.646 & .316 \\
Master's & 17 & 1.953 & .476 \\
PhD & 3 & 1.804 & .432 \\
\hline
\end{tabular}

avoidant laissez-faire (LF) $22.7 \%$ of participants scored 2.00 with a mean of 1.95 and standard deviation of .422 .

\section{Effects of Education}

An analysis of the directors' self-perception of their leadership characteristics using the $M L Q$ Short form (transformational, transactional, and passive avoidant), the $M L Q$ Short form outcomes of leadership (extra effort, effectiveness, and satisfaction), and education included 62 participants. The descriptives for the comparison of transformational leadership and education (Table 4) were as follows: high school $\mathrm{N}=3$ with mean of 4.1667 and standard deviation .45369 ; CDA N $=13$ with mean of 3.9615 and standard deviation .50627; Associates $\mathrm{N}=6$ with mean of 4.4139 and standard deviation 3.40186; Bachelors $\mathrm{N}=20$ with mean of 4.3592 and standard deviation .46426; masters $\mathrm{N}=17$ with mean of 4.2902 and standard deviation .61198; and $\mathrm{PhD} \mathrm{N}=3$ with mean of 4.3667 and standard deviation .45369 .

The descriptives for the comparison of transactional leadership and education were as follows: high school $\mathrm{N}=3$ with mean of 3.9167 and standard deviation .26021; CDA $\mathrm{N}=13$ with mean of 3.5160 and standard deviation .64942 ; associate $\mathrm{N}=6$ with mean of 3.7847 and standard deviation .34603 ; bachelor's $\mathrm{N}=20$ with mean of 3.6917 and standard deviation .47573; master's $\mathrm{N}=17$ with mean of 3.5000 and standard deviation .47573; and $\mathrm{PhD} \mathrm{N}=3$ with mean of 3.7083 and standard deviation .38188 .

The descriptives for the comparison of passive/avoidant leadership and education with $\mathrm{N}=62$ (Four participants chose not to reveal their educational level) were as follows: high school $\mathrm{N}=3$ with mean of 1.8333 and standard deviation .19094; CDA N=13 with mean of 1.9904 and standard deviation .52157 ; associate $\mathrm{N}=6$ with mean of 1.5417 and

Table 5 Education and extra effort correlations

\begin{tabular}{|c|c|c|c|c|}
\hline & & & Education & Extra effort \\
\hline \multirow[t]{7}{*}{ Kendall's Tau_b } & Education & Correlation coefficient & 1.000 & .276 \\
\hline & & Sig (2 tailed) & & .007 \\
\hline & & $\mathrm{N}$ & 62 & 61 \\
\hline & Extra Effort & Correlation coefficient & .276 & 1.000 \\
\hline & & Sig (2 tailed) & .007 & \\
\hline & & $\mathrm{N}$ & 61 & 62 \\
\hline & & & Education & Effectiveness \\
\hline \multirow[t]{6}{*}{ Kendall's Tau_b } & Education & Correlation coefficient & 1.000 & .213 \\
\hline & & Sig (2 tailed $)$ & & .036 \\
\hline & & $\mathrm{N}$ & 62 & 61 \\
\hline & Extra Effort & Correlation coefficient & .213 & 1.000 \\
\hline & & Sig (2 tailed) & .036 & \\
\hline & & $\mathrm{N}$ & 61 & 62 \\
\hline
\end{tabular}


standard deviation .30277; bachelor's $\mathrm{N}=20$ with mean of 1.6458 and standard deviation .31603 ; master's $\mathrm{N}=17$ with mean of 1.9534 and standard deviation .47573; $\mathrm{PhD} \mathrm{N}=3$ with mean of 1.8044 and standard deviation .43193 .

\section{Education Level and Extra Effort and Effectiveness}

The Kendal tau_b correlation (Table 5) determined there were statistically significant relationships between the survey instruments measures of characteristic of outcomes of leaderships scale, extra effort (MLQ 5X Short self-form) and the education of the participants which produced a .276 moderate correlation $(\mathrm{p}=.007)$. Then the researcher checked the t-test (Hinkle et al., 2003) and found a significant correlation between participants who have a bachelor's or master's degrees with high levels of extra effort $($ mean $=4.13)$ and effectiveness (mean $=4.28$ ).

\section{Discussion}

The general purpose of this study was to contribute to the literature on leadership in childcare, as there is limited research on early childhood leadership (Berger, 2016; Goffin \& Janke, 2013). Specifically, we sought to determine if childcare directors possessed leadership styles recognized in the literature as effective, and which characteristics impacted the director's leadership style. The findings echo the literature on professional development that "directors with greater levels of administrative training report significant gains in their level of competence" and growth within their organizational structure (Talan et al., 2014, p. 2). The largest contributing factor to these results was the childcare center directors' education. Overall, most of the childcare directors self-identified with transformational leadership, which has been identified in the literature as the most effective leadership style (Rusliza \& Fawzy, 2016). This is a significant finding, as previous literature often characterizes childcare leaders as primarily managers who are unprepared for leadership roles (Bloom, 1997; Bloom et al., 2013; Talan et al., 2014).

The directors answered questions from the MLQ Short form, examining their own leadership behaviors, interactions and circumstances with which these interactions took place (Bem, 1972). The results self- identified directors as possessing "individualized support, shared goals, vision, intellectual stimulation, culture building, rewards, high expectations, and modeling" (Hallinger, 2003, p. 335) which is unrelated to a manager, but rather one who motivates and inspires others by providing a "positive impact on work performance" (Rusliza \& Fawzy, 2016, p. 206). This also is linked to the literature on leadership models (Bush \& Glover, 2014) as this study has illuminated childcare directors' transformational leadership styles which can inform and lead to changes in childcare leadership practices and research. Previous research (Alatawi, 2017) suggests that transformational leadership can reduce turnover, which at present in the field of childcare is 30\% nationally (Casey Family Programs, 2019).

The $M L Q$ Short form breaks down the transformational leadership characteristics into five specific characteristic areas including idealized attributes, idealized behaviors, inspirational motivation, intellectual stimulation, and individual consideration. The overall positive response regarding transformational leadership style resulted with the highest frequency (fairly often) of respondents relating specifically to inspirational motivation and individualized consideration. These two characteristics are consistent with the literature (Coleman et al., 2015) and connect the qualities of a high performing leader to the Herzberg theory (Herzberg et al., 1959) and self-determination theory (Deci \& Ryan, 2012). The Herzberg theory is entwined with inspirational motivation-a leader who is encouraging, optimistic and enthusiastic "clarifies expectations and offers recognition when goals are achieved...result in individuals and groups achieving expected levels of performance" (Avolio et al., 2004, p. 104). Self-determination includes facilitating functioning of those surrounding you and the characteristic of individualized consideration includes being able to understand one's staff as individuals and support them to develop their strengths promoting empowerment of staff.

The directors' responses related to transactional leadership identified most of the respondents scoring this characteristic as sometimes present within their leadership. This is significant as leaders should want to avoid embodying the characteristics of transactional leadership, as this style can be more connected to management (i.e., supervision and productivity) (Northouse, 2016), which is how much of the literature often characterizes childcare directors (Bloom, 1997; Bloom et al., 2013; Talan et al., 2014). This characterization sheds light on the struggle of childcare directors who sometimes have the mindset of a manager.

In relation to the scores of passive/avoidant leadership, the respondents scored this between not at all or once in $a$ while. This is a significant finding as previous literature (Ang, 2012; Coleman et al., 2015; Muijs et al., 2004; SirajBlatchford \& Manni, 2006) related childcare leaders to teachers and managers which would lead to the assumption they would be more passive and "react only after problems have become serious to take corrective action and may avoid making any decisions." (Avolio et al., 2004, p. 53). However, the childcare directors in this study scored this lower signifying they are trying to avoid the mindset of a passive/ avoidant leader.

The study investigated directors' self-perception of their leadership style as it related to their education level. The literature says leaders must have acquired formal 
education and quality experiences to possess effective leadership styles and practices (O'Connor, 2011; Rich \& Porter-O'Grady, 2011). Results from this study indicated that those with more education were more likely to self-identify with transformational leadership than those with a CDA or a high school diploma. This finding is consistent with previous literature, which identifies that "[t]hose with more education may be more likely to use feedback and process information from others in such a way that their self-ratings are more closely aligned with ratings from others" (Ostroff et al., 2004, p. 338)". This finding is consistent with self-determination theory (Deci \& Ryan, 2012); increased education can be viewed as evidence of an individual who is motivated and aware of what is needed to be productive in each area.

These results suggest that education is aligned with transformational leadership, which echoes the call from the literature on the need for professional development for childcare leaders (Talan et al., 2014). Although, there is programming that exists for local directors to acquire state approved professional development in the state where this study took place, this credential is not mandatory. Unfortunately, we do not yet have in childcare the elaborate system of professional credentialing for leaders as is in place for K-12 administrators. Principals in K-12 schools must have a master's degree, state certification, five or more years of classroom teaching at the school level, and a minimum of 27 semester hours of graduate credit. If our sample had these prerequisites for the position of childcare director, our results may have looked different.

Interestingly, respondents with the education level of both master's and CDA provided higher values passive/ avoidant mean. This could be explained by two things: respondents holding a CDA did not have as much education and those respondents with master's degrees did not have as much experience working in childcare before becoming administrators (less than two years). Overall, respondents who scored the lowest for passive/avoidant leadership were those with associate degrees; this could be related to both their experience in childcare combined with their training related to the field.

These data showed a correlation between outcomes of leadership extra effort and the education of the respondent, as well as education and outcomes of leadership effectiveness. This meant that the respondents with higher education, particularly bachelor's and master's degrees, exhibited these outcomes of leadership (extra effort and effectiveness). The amount of education the respondent received (formal education or professional development), allows one to improve one's leadership skills such as research, marketing, communication with policy makers and risk taking, to promote high-quality programs (Rodd, 1997). The literature explains that extra effort and effectiveness can be related to a transformational or transactional leader in that these characteristics are outcomes of the leadership styles. Extra effort means one can motivate others to increase their productivity, boost others' drive, and eagerness to try harder. For effectiveness the leader meets employees "job-related needs... [while] representing their organization [to others] and meeting organizational requirements" (Avolio et al., 2004, p. 105).

\section{Limitations}

Some suggest electronic surveys can be a limitation due to limited computer skills or access to technology, but one must evaluate the study, goals, ethical considerations, and respondents one is trying to reach (Nardi, 2018). This selfreport method did have some limitations including some questions being incomplete (Creswell, 2014) or "perceptual biases" (Metts et al., 1991, p. 169) or "response bias" (CelisMorales et al., 2012, p. 2), and potential for misinterpretation of items on the questionnaire (Demetriou et al., 2015). The literature related to response rates for online surveys versus paper based, alludes to the fact that paper is more effective. However, if online surveys are distributed with a push and followed with reminders the response rate is predictably higher (Nulty, 2008; Saleh \& Bista, 2017). An additional consideration was that these data were collected during the initial school closures due to the COVID-19 pandemic in the spring of 2020. The procedures and protocols put in place in child care centers likely impacted the response rate of child care directors.

\section{Implications}

There are implications for several stakeholder groups in early care related to the outcomes of this research-policy makers, teacher preparation programs, business owners, early care administrators, and childcare teachers. The field of early care should consider policy standards in the credentialing of their administration, considering findings from the present study and past research (Rodd, 1997). Guidance could be found in reviewing administrative credentials from both the Educational Teacher preparation programs to consider inclusion of content from the administration standards for K-12 schools (Marks \& Printy, 2003) and from childcare administrator credentialing (e.g., Pathways) in the creation of an administrative certification pathway for childcare administrators or for inclusion in Birth to Five teacher certification programs. Business owners of childcare centers should consider the education level of their directors and consider characteristics of transformational leadership when interviewing potential 
administrators, as hiring transformational leaders is correlated with lower turnover of employees (Alatawi, 2017). Childcare administrators seeking professional development and growth in their organization should study the characteristics of transformational leadership (Hallinger, 1992; Northouse, 2016; Rusliza \& Fawzy, 2016). Childcare teachers should consider characteristics of transformational leaders when both interviewing for positions in early care environments, as these leaders are more likely to support them as a positive role model and in their own professional development, if they intend to lead in the future.

\section{Conclusion}

This study adds significant value to the body of literature on early care leadership as the results suggest that education is beneficial to determining leadership styles. In general, these results suggest that early care leaders who remain in the role of managers (displaying either transactional or passive/avoidant leadership styles) will not be able to provide the leadership needed to provide high quality of education for young children (Ang, 2012; Coleman et al., 2015; Muijs et al., 2004; Siraj-Blatchford \& Manni, 2006).

In closing, research suggests that childcare leaders would benefit from educational experiences to develop their leadership skills to more closely align with characteristics associated with transformational leadership. Kellerman (2013) explains that leadership should be "conceptualized as an equilateral triangle" (p. 137); the three sides, equally important, include the leader, followers, and context. A transformational leader can inspire confidence in staff and create an environment conducive to professional growth and development.

\section{References}

Alatawi, M. A. (2017). Can transformational managers control turnover intention? SA Journal of Human Resource Management. https:// doi.org/10.4102/sajhrm.v15i0.873

Amanchukwu, R., Stanley, G. \& Ololube, N. P. (2015). A Review of Leadership Theories, Principles and Styles and Their Relevance to Educational ManagementManagement,5(1),6-14https://doi.org/ 10.5923/j.mm.20150501.02

Ang, L. (2012). Leading and managing in the early years: A study of the impact of a NCSL programme on children's centre leaders' perceptions of leadership and practice. Educational Management Administration \& Leadership, 40(3), 289-304. https://doi.org/10. $1177 / 1741143212436960$

Antonakis, J., Avolio, B. J., \& Sivasubramaniam, N. (2003). Context and leadership: An examination of the nine-factor full-range leadership theory using the Multifactor Leadership Questionnaire. The Leadership Quarterly, 14(3), 261-295. https://doi.org/10.1016/ S1048-9843(03)00030-4
Avolio, B. J., Bass, B. M., \& Zhu, F. W. W. (2004). Multifactor leadership questionnaire: Manual and sampler set. Mind Garden Inc.

Bass, B. M., \& Avolio, B. J. (1995). Multifactor Leadership Questionnaire for Research. Mind Garden Inc.

Bateson, M. C. (1989). Composing a life. Atlantic Monthly Press.

Bem, D. J. (1972). Self-perception theory. Advances in Experimental Social Psychology, 6, 1-62. https://doi.org/10.1016/S00652601(08)60024-6

Berger, I. (2016). Pedagogical nations and leadership in early childhood education as thinking in moments of not knowing. Journal of Childhood Studies. https://doi.org/10.18357/jcs.v40i1.15215

Bloom, P. J. (1997). Navigating the rapids: Directors reflect on their career and professional development. Young Children, 52(7), 32-38.

Bloom, P. J. (2000). How do we define director competence? Child Care Information Exchange, 138, 13-18.

Bloom, P. J., Jackson, S., Talan, T. N., \& Kelton, R. (2013). Taking charge of change: A 20-year review of empowering early childhood administrators through leadership training. McCormick Center for Early Childhood Leadership, National Louis University.

Burns, J. M. (1979). Leadership. Harper \& Row.

Bush, T., \& Glover, D. (2014). School leadership models: What do we know? School Leadership \& Management, 34(5), 553-571. https://doi.org/10.1080/13632434.2014.928680

Casey Family Programs. (2019, November 25). How does turnover affect outcomes. Casey Family Programs. https://www.casey. org/turnover-costs-and-retention-strategies/

Celis-Morales, C. A., Perez-Brave, F., Ibañez, L., Salas, C., Bailey, M. E. S., \& Gill, J. M. R. (2012). Objective vs self-reported physical activity and sedentary time: Effects of measurement method on relationships with risk biomarkers. PLOS ONE. https://doi.org/10.1371/journal.pone.0036345

Charry, K. (2012). Leadership Theories: 8 Major Leadership Theories. http://psychology.about.com/od/leadership/p/leadtheori es.htm

Coleman, A., Sharp, C., \& Handscomb, G. (2015). Leading highly performing children centers: Supporting the development of the 'accidental leaders.' Educational Management Administration \& Leadership, 44(5), 775-793. https://doi.org/10.1177/1741143215 574506

Creswell, J. W. (2014). Research design: Qualitative, quantitative, and mixed approaches (4th Edition). SAGE Publications Inc.

Deci, E. L., \& Ryan, R. M. (2012). Self-determination theory. In P. A. M. Van Lange, A. W. Kruglanski, \& E. T. Higgins (Eds.), Handbook of theories of social psychology (pp. 416-436). Sage Publications Ltd. https://doi.org/10.4135/9781446249215.n21

Demetriou, C., Özer, B. U., \& Essau, C. A. (2015). Self-report questionnaires. In R.L. Cautin \& S.O. Lilienfeld (Eds.), The encyclopedia of clinical psychology (1st ed., pp. 1-6). Wiley. https://doi. org/10.1002/9781118625392.wbecp507

Fryrear, A. (2019). What's a good survey response rate? Alchemer. https://www.surveygizmo.com/resources/blog/survey-respo nse-rates/

Goffin, S., \& Janke, M. (2013). Early childhood education leadership development compendium: A view of the current landscape (2nd ed.). Goffin Strategy Group.

Hallinger, P. (1992). The evolving role of American principals: From managerial to instructional to transformational leaders. Journal of Educational Administration, 30(3), 35-48. https://doi.org/10. 1108/09578239210014306/full/html

Hallinger, P. (2003). Leading educational change: Reflections on the practice of instructional and transformational leadership. Cambridge Journal of Education, 33(3), 329-352. https://doi.org/10. 1080/0305764032000122005

Hard, L., \& Jónsdóttir, A. H. (2013). Leadership is not a dirty word: Exploring and embracing leadership in ECEC. European Early 
Childhood Education Research Journal, 21(3), 311-325. https:// doi.org/10.1080/1350293X.2013.814355

Herzberg, F., Mausner, B., \& Snyderman, B. B. (1959). The motivation to work. Wiley.

Hinkle, D. E., Wiersma, W., \& Jurs, S. G. (2003). Applied statistics for the behavioral sciences. Houghton Mifflin Company.

Kellerman, B. (2013). Leading questions: The end of leadership-redux. Leadership, 9(1), 135-139. https://doi.org/10.1177/1742715012 455132

Louisiana Department of Education (2021, August 14). Louisiana Early Learning Center Licensing Regulations (Bulletin 137). https://www.louisianabelieves.com/early-childhood/child-careand-development-fund-licensing

Marks, H. M., \& Printy, S. M. (2003). Principal leadership and school performance: An integration of transformational and instructional leadership. Educational Administration Quarterly, 39(3), 370397. https://doi.org/10.1177/0013161X03253412

McCormick Center for Early Childhood Leadership. (2021, August 14). Leadership academies. Leadership Academies I McCormick Center for Early Childhood Leadership. https://mccormickcenter. nl.edu/services/leadership-academies/

Metts, S., Sprecher, S., \& Cupach, W. R. (1991). Retrospective selfreports. In B. M. Montgomery \& S. Ducks (Eds.), Studying interpersonal interaction (pp. 162-178). Guilford Press.

Muijs, D., Aubrey, C., Harris, A., \& Briggs, M. (2004). How do they manage? Journal of Early Childhood Research, 2(2), 157-169. https://doi.org/10.1177/1476718X04042974

Nardi, P. M. (2018). Doing survey research: A guide to quantitative methods. Routledge.

Nulty, D. D. (2008). The adequacy of response rates to online and paper surveys: What can be done? Assessment \& Evaluation in Higher Education, 33(3), 301-314. https://doi.org/10.1080/02602 930701293231

Northouse, P. G. (2016). Leadership: Theory and practice. SAGE Publications.

O'Connor, M. (2011). Beyond the classroom: Nurse leadership preparation and practices. Nursing Administration Quarterly, 35(4), 333-337. https://doi.org/10.23937/2469-5823/1510132

Ostroff, C., Atwater, L. E., \& Feinberg, B. J. (2004). Understanding self-other agreement: A look at rater and ratee characteristics, context, and outcomes. Personnel Psychology, 57(2), 333-375. https://doi.org/10.1111/j.1744-6570.2004.tb02494.x

Parsons, M. B., Reid, D. H., \& Crow, R. E. (2003). Best and worst ways to motivate staff in community agencies: A brief survey of supervisors. Mental Retardation, 41(2), 96-102. https://doi.org/ 10.1352/0047-6765(2003)0412.0.co;2
Rich, V. L., \& Porter-O'Grady, T. (2011). Nurse executive practice: Creating a new vision for leadership. Nursing Administration Quarterly, 35(3), 277-281.

Rodd, J. (1997). Learning to be leaders: Perceptions of early childhood professionals about leadership roles and responsibilities. Early Years, 18(1), 40-46.

Rodd, J. (2006). Leadership in early childhood (3rd ed.). Open University Press.

Rusliza, Y., \& Fawzy, E. (2016). Leadership styles and organizational commitment: Literature review. Journal of Management Development, 35(2), 190-216. https://doi.org/10.1108/JMD-01-2015-0004

Saleh, A., \& Bista, K. (2017). Examining factors impacting online survey response rates in educational research: Perceptions of graduate students. Journal of MultiDisciplinary Evaluation, 13(29), $63-74$.

Scott, D. (2020). 50-State comparison: School Leader certification and preparation programs. Education Commission of the States. https://www.ecs.org/50-state-comparison-school-leader-certificat ion-and-preparation-programs/

Siraj-Blatchford, I. \& Manni, L. (2006). Effective leadership in the early years. Institute of Education, University of London. https:// www.researchgate.net/profile/Iram-Siraj/publication/267839273_ Effective_Leadership_in_the_Early_Years_Sector_ELEYS_ Study_Authors/links/54b8ebc30cf2c27adc490498/EffectiveLeadership-in-the-Early-Years-Sector-ELEYS-Study-Authors.pdf

Talan, T. N., Bloom, P. J., \& Kelton, R. E. (2014). Building the leadership capacity of early childhood directors: An evaluation of a leadership development model. Early Childhood Research \& Practice, 16(1), 5231.

Wise, V., \& Wright, T. (2012). Critical absence in the field of educational administration: Framing the (missing) discourse of leadership in early childhood settings. International Journal of Educational Leadership Preparation, 7(2), 1-10.

Wolcott, H. F. (2003). The man in the principal's office: An ethnography. AltaMira Press.

World Population Review. Louisiana Population 2021 (Demographics, Maps, Graphs). https://worldpopulationreview.com/states/ louisiana-population

Publisher's Note Springer Nature remains neutral with regard to jurisdictional claims in published maps and institutional affiliations. 